\title{
The Relationship Among Spiritual Intelligence, Emotional Intelligence, Organizational Citizenship Behaviour, and Employee Performance
}

\author{
Achmad Sani Supriyanto ${ }^{1 *}$, Vivin Maharani Ekowati ${ }^{2}$, Masyhuri ${ }^{3}$ \\ *Corresponding author
}

\begin{abstract}
The effect of Intelligence on employee performance is highly essential, although contradictions related to the current research found. This research aims to analyze the direct and indirect effect of spiritual intelligence and emotional intelligence on employee performance through Organizational Citizenship Behavior (OCB). This research using Partial Least Square (PLS) with 50 respondents as samples. It shows that emotional intelligence has a direct and indirect effect on employee performance. Meanwhile, spiritual intelligence only has a direct effect on employee performance. Emotional intelligence can increase employee performance indirectly through OCB. Management implies that the supervisor is supposed to conduct an assessment on $O C B$ to enhance employee performance continuously.
\end{abstract}

Keywords: spiritual intelligence, emotional intelligence, organizational citizenship behavior, performance

JEL Classification: D23, J24

\begin{abstract}
Abstrak. Pengaruh kecerdasan terhadap kinerja karyawan sangat penting. Meskipun masih ada kontradiksi hasil penelitian. Penelitian ini bertujuan untuk menganalisis pengaruh kecerdasan spiritual dan kecerdasan emosional terhadap kinerja karyawan secara langsung dan secara tidak langsung melalui Organizational Citizenship Behavior (OCB). Analisis data menggunakan Partial Least Square (PLS). Sampel peelitian sebanyak 50 responden. Hasil penelitian menunjukkan kecerdasan emosional berpengaruh terhadap kinerja pegawai baik secara langsung maupun tidak langsung. Sedangkan kecerdasan spiritual hanya berpengaruh secara langsung terhadap kinerja pegawai. Kecerdasan emosional dapat meningkatkan kinerja pegawai secara tidak langsung melalui OCB. Implikasi manajerial dari penelitian ini adalah pimpinan seharusnya melakukan penilaian terhadap OCB secara terus menerus sehingga dapat semakin meningkatkan kinerja pegawai.
\end{abstract}

Kata Kunci: kecerdasan spiritual, kecerdasan emosional, organizational citizenship behavior, kinerja

\section{How to Cite:}

Supriyanto, A. S., Ekowati, V. M., \& Masyhuri. (2019). The Relationship Among Spiritual Intelligence, Emotional Intelligence, Organizational Citizenship Behaviour, and Employee Performance. Etikonomi: Jurnal Ekonomi. Vol. 18 (2): 249 - 258. doi: http//dx.doi.org/10.15408/etk.v18i2.11318. 


\section{Introduction}

Organizational Citizenship Behavior (OCB) is a voluntary challenge that may increase the effectiveness of an organization. OCB has not considered an integral part of official rules and regulations (Anwar \& Osman-Gani, 2015). Strategic action in Human Relations is to develop organizational citizenship behavior over an organization. OCB can contribute to organizational effectiveness through managerial productivity and performance, enable organizations to adapt to environmental changes, and strengthen the communication within a workplace (Podsakoff et al., 2000). OCB has a necessary consequence in the workplace (Arvind et al., 2015). Organ (2006) suggests that employee involvement in the extra work can be weak for the social system, and it will soon crush in competition.

OCB never found within the employee job description, but it is necessary. It will increase the effectiveness and survival of an organization or company, especially in a business environment with high competition. Someone with high OCB will not pay with money or specific bonuses, but the OCB is a social behavior of every individual to work beyond expectation, such as creating a pleasant mood at work, giving suggestions, and not wasting time during the work (Robbins, 2006).

The performance of the employees mostly determines company performance. Therefore, examining employee performance is essential. Employee performance is influential for the success of an organization. An organization must improve employee performance. Employee performance is the result of employees' work in quality and quantity following his responsibilities (Mangkunegara, 2001). Another concerning factor is that how to measure the role of OCB on employee performance. A comfortable, safe, and conducive work environment will create when employees demonstrate Organizational Citizenship Behavior (Gan \& Yusof, 2018).

Employees with OCB will have high expectations to achieve high achievement, under the presupposition that the organization management sees the essential factors to shape the employee performance in terms of both work environment and OCB. According to Luthans (2011), OCB has a close relationship with individual performance, group performance, and organizational performance. Maharani et al., (2013), Basu et al., (2017) find out a significant effect of OCB on employee performance. Indarti, et al. ( 2017) examines the effect of OCB and job satisfaction on employee performance. This study shows that job satisfaction can increase performance through OCB. Therefore, OCB theoretically has a positive relationship with employee performance.

Spiritual intelligence is related to mental awareness of the meaning of life. With a higher level of spirituality, somebody can have better inspirations for their work. The one with the right level of spiritual intelligence may be an asset to the organization. Therefore, it is necessary to consider the effects of spiritual intelligence on OCB (Anwar \& Osman-Gani, 2015). The result is in line with the research by (Rahgozar et al., 2014), which suggests a positive relationship between spiritual intelligence and OCB among staff at Shiraz Azad University.

Intelligence is a significant contributor to affect the OCB level. Emotional intelligence is an employee's ability to understand, to regulate, and to assess emotions and feelings (Mayer et al., 2004). Emotional intelligence is one of the best tools to improve employee relations to 
develop social relations among co-workers (Siddiqui \& Hassan, 2013). Emotional intelligence does not correlate with heredity. Thus, it opens up opportunities to continue what nature has provided to a higher chance of achieving success. Emotional intelligence has a large and vital role in achieving success at work and in the community (Saphiro, 2003).

The effect of emotional intelligence on OCB is also explained by Bighami et al. (2013). He proves a positive relationship between emotional intelligence and OCB. On the other hand, Chin et al. (2011) find out that there is almost no correlation between emotional intelligence and OCB. Thus, research about it is still interesting to review.

Emotional intelligence does not go against intellectual intelligence. However, both interact dynamically at the conceptual level and the real world. Students have an intelligent contribution to organizational success, but there is still little research to link it with employee behavior (Meisler, 2013). Khawaja, (2017) finds a positive relationship between OCB, performance, and OCB. (Muhdar \& Rahma, 2015) also suggests the same result, that spiritual intelligence and OCB influence performance.

Although many studies show a high influence of intelligence on performance (Khawaja, 2017; Muhdar \& Rahma, 2015), a gap to conduct a research on it is still open (Meisler, 2013). Studies to understand human intelligence as the antecedent of OCB in the workplace have rarely conduct while supervisors demand on clear understandings of this construct that can provide a significant knowledge of spiritual experience in response to the organizational relationship.

The current study aims to explore performance perspective and socioemotional selective theory within an organizational citizenship behavior and performance at the workplace. Therefore, spiritual intelligence, emotional intelligence, organizational citizenship behavior, and performance can understand in terms of theory and practice.

\section{Method}

The current research is explanatory. It aims to examine the direct and indirect effect of emotional intelligence and spiritual intelligence on employee performance with OCB as an intervening variable. This research is conduct in Bank of BTN shariah, Malang. The samples are active employees from Bank of BTN shariah, Malang. The sample consists of 50 respondents. The indicators of emotional intelligence refer to Sani \& Troena (2012). he spiritual intelligence instrument based on the concept of Agustian (2007). The researcher refers to Podsakoff et al. (2000) to measure the OCB-indicator, and also Mangkunegara (2001) to measure the employee performance.

Data are analysed using Partial Least Square (PLS). It is used to analyse the influence of emotional intelligence and spiritual intelligence on employee performance through OCB. OCB variable used as an intervening variable. Khawaja (2017) suggests that spiritual intelligence has a positive effect on OCB and performance. Muhdar \& Rahma (2015) show that spiritual intelligence influences OCB and performance. Anwar \& Osman-Gani (2015) show that spiritual intelligence influences OCB, and Bighami et al. (2013) show a positive relationship between emotional intelligence on OCB. Figure 1 shows the Path Analysis Model from this research. 
Figure 1. Path Analysis Model

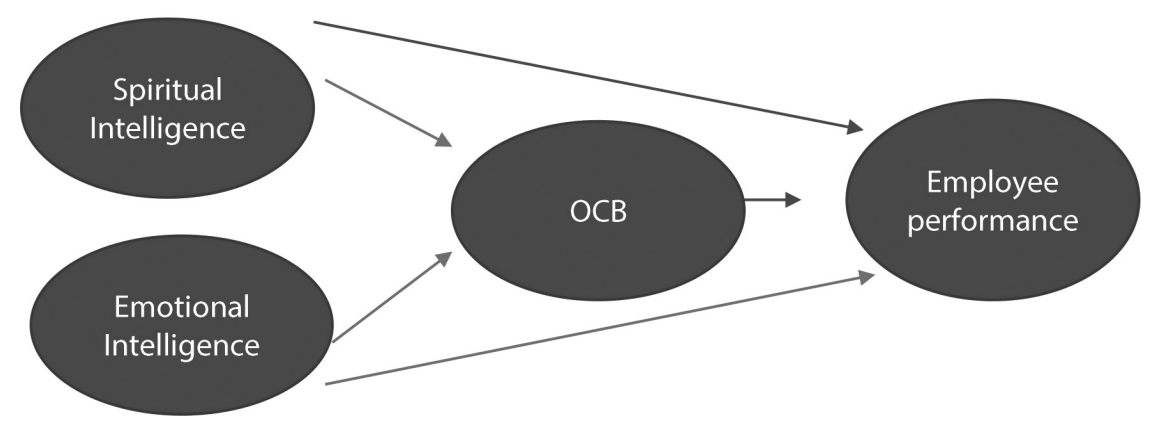

The descriptive analysis describes how to implement spiritual intelligence and emotional intelligence based on the characteristics of respondents. To identify the implementation of OCB and employee performance, the researcher employs descriptive analysis, which includes cross-tabulation. Data analyzed by using PLS software to explain path analysis among variables.

\section{Results and Discussion}

The respondents of the current study are 28 men (56\%) and 22 women (44\%), as provided in Table 1. It indicates that employees in the Islamic Bank, Malang, are still dominated by men. The descriptive analysis of 50 respondents shows that the most significant number of respondents are 26-35 years old, which is $48 \%$. Besides, $15(30 \%)$ respondents are 15-25 years old, and 11 (22\%) respondents are 36-45 years old.

Table 1. Distribution of Sample

\begin{tabular}{cccc}
\hline Variable & Variables Categorie & Number & $\%$ \\
\hline Sex group & Male & 28 & 56 \\
& Female & 22 & 44 \\
Age Group & $15-25$ & 15 & 30 \\
& $26-35$ & 24 & 48 \\
Marital Status & $36-45$ & 11 & 22 \\
& Married & 33 & 66 \\
Education & Single & 17 & 34 \\
& Widow & 0 & 30 \\
Experience & Dachelor degree & 15 & 70 \\
& Diploma degree & 35 & 4 \\
& Less than 1 year & 2 & 22 \\
& More than 5 years & 11 & 74 \\
\hline
\end{tabular}

The aspect of marital status, 33 respondents (66\%) married, 17 of them (34\%) are single, and $0(0 \%)$ is a widow. In the education level, 15 respondents $(30 \%)$ are a bachelor, 
and $35(70 \%)$ of them are the diploma. In terms of working experience, 11 respondents $(22 \%)$ have been working for $1-5$ years, two respondents (4\%) with less than 1-year work experience, and 37 (74\%) of them have more than 5-year experience.

The evaluation of the measurement model validated the result of the loading factor. Variables should be valid to construct if the standard of loading factor is $\geq 0.50$. While, the Cronbach Reliability is supposed to be $\geq 0.70$. The Average Variance Extracted (AVE $\geq 0.50$ ) is used to measure the reliability in PLS measurement. All manifested variables to latent variables validate that all values of the loading factor are $\geq 0.50$. Cronbach Reliability $(C R) \geq$ 0.70 concludes that all latent variables have good reliabilities.

Table 2. The Evaluation of Measurement Model (Outer Model)

\begin{tabular}{|c|c|c|c|c|c|c|c|}
\hline \multirow[t]{2}{*}{ Latent Variable } & \multirow[t]{2}{*}{$\begin{array}{c}\text { Observed } \\
\text { Variable }\end{array}$} & \multicolumn{4}{|c|}{ Convergent Validity } & \multicolumn{2}{|c|}{$\begin{array}{c}\text { Cronbach Reliability } \\
(C R>0.7)\end{array}$} \\
\hline & & $\begin{array}{l}\text { Loading } \\
\text { Factors }\end{array}$ & Results & AVE & Result & CR & Result \\
\hline Spiritual & $\mathrm{X} 1.1$ & 0.885 & Valid & 0.881 & Valid & 0.953 & Reliable \\
\hline \multirow[t]{5}{*}{ Intelligence } & $\mathrm{X} 1.2$ & 0.735 & Valid & & & & \\
\hline & $\mathrm{X} 1.3$ & 0.761 & Valid & & & & \\
\hline & $\mathrm{X} 1.4$ & 0.880 & Valid & & & & \\
\hline & $\mathrm{X} 1.5$ & 0.757 & Valid & & & & \\
\hline & $\mathrm{X} 1.6$ & 0.753 & Valid & 0.636 & & 0.913 & \\
\hline Emotional & $X 2.1$ & 0.934 & Valid & & Valid & & Reliable \\
\hline Intelligence & $\mathrm{X} 2.2$ & 0.944 & Valid & 0.871 & & 0.937 & \\
\hline \multirow[t]{3}{*}{ OCB } & Y1.1 & 0.777 & Valid & & Valid & & Reliable \\
\hline & $\mathrm{Y} 1.2$ & 0.969 & Valid & & & & \\
\hline & Y1.3 & 0.813 & Valid & 0.734 & & 0.892 & \\
\hline Employee & Y2.1 & 0.934 & Valid & & & & \\
\hline \multirow[t]{2}{*}{ Performance } & $\mathrm{Y} 2.2$ & 0.893 & Valid & & Valid & & Reliable \\
\hline & Y2.3 & 0.971 & Valid & & & & \\
\hline
\end{tabular}

The tests divided into four main steps: 1) testing the direct effect of spiritual intelligence on employee performance; 2) testing the direct effect of emotional intelligence on employee performance; 3) testing the indirect effect of spiritual intelligence on employee performance through OCB; and 4) testing the indirect effect of emotional intelligence on employee performance through $\mathrm{OCB}$ - the summary of the test result provided in Table 3.

In the first step, spiritual intelligence has a significant effect on employee performance, so the result supports hypothesis 1 . Spiritual intelligence increases employee performance directly. Employee performance covers working quantity and quality and Timeliness. The second step shows that emotional intelligence has a significant effect on employee performance. Hence, hypothesis 2 is in line with the examination result. The third examination shows that spiritual intelligence can have a positive effect on OCB. OCB plays a vital role in employee performance. Hence, hypothesis 3 does not agree with the result. Spiritual intelligence cannot increase employee performance through OCB. The indirect influence of spiritual intelligence on employee performance is 0.016 , while the direct one is 0.157 (See Figure 3) based on the coefficient. It concludes that the direct influence of spiritual intelligence to employee 
performance is higher than the indirect effect. Spiritual intelligence can have a positive effect on employee performance (Anwar \& Osman-Gani, 2015). However, it has different results from that of Khawaja (2017). He finds out that OCB is a mediation variable between spiritual intelligence and performance.

Table 3. Hypothesis Testing Results

\begin{tabular}{lccccc}
\hline & Original Sample & Sample Mean & Standard Deviation & T Statistics & P-Value \\
\hline $\begin{array}{l}\text { Emotional Intelligence } \\
\rightarrow \text { Performance }\end{array}$ & 1.112 & 1.044 & 0.155 & 7.180 & 0.000 \\
$\begin{array}{l}\text { Emotional Intelligence } \\
\rightarrow \text { OCB }\end{array}$ & 0.794 & 0.774 & 0.122 & 6.527 & 0.000 \\
$\begin{array}{l}\text { Spiritual Intelligence } \\
\rightarrow \text { Performance }\end{array}$ & 0.157 & 0.164 & 0.075 & 2.101 & 0.033 \\
$\begin{array}{l}\text { Spiritual Intelligence } \\
\rightarrow \text { OCB }\end{array}$ & 0.045 & 0.075 & 0.143 & 0.315 & 0.731 \\
OCB $\rightarrow$ Performance & 0.350 & 0.284 & 0.185 & 1.994 & 0.032 \\
\hline
\end{tabular}

Anwar \& Osman-Gani (2015) claim that spiritual intelligence is happy enough to do their work correctly. When somebody is cheerful in his mind, he or she may be happy during working. People will be more active to involve in any activity within the organization. Furthermore, the dimensions of spiritual intelligence and organizational justice are positively related. It shows that a worker with high organizational competence will indirectly lead to behavior exceeding his role (OCB). Without organizational competence, they may not work beyond what they are supposed to do.

The fourth step shows that emotional intelligence has a significant effect on OCB, and OCB increases employee performance. Therefore, hypothesis 4 goes in compliance with the result of the study. Emotional intelligence can increase employee performance through OCB. The indirect influence of emotional intelligence on employee performance is 0.278 , while the direct one is 1.112 (See Figure 2) based on the coefficient. The direct effect of emotional intelligence on employee performance is higher than the indirect one. Emotional intelligence can have a positive effect on OCB and employee performance (Bighami et al., 2013). Chelagat et al. (2015), Harwiki (2016), and Indarti et al. (2017) state that OCB and employee performance have a close relation. According to Overstreet (2016), emotional intelligence has a positive effect on performance and mediated by OCB variables. Rezvani et al., (2018) suggest that Emotional Intelligence correlates with performance. One of the main factors determining organizational effectiveness is emotional intelligence (Stephens \& Carmeli, 2016). Emotional intelligence is the capacity to support and control personal emotions and others.

Employees with good emotion quotient can control their behavior in the work environment. A problem over the work can solve through discussion or deliberation. Employees who have a high motivation can provide excellent results over the work. Besides, they can also be a figure for other employees to solve a particular problem. 
This study shows that emotional intelligence can increase performance through OCB. Employees with good emotional intelligence are aware of the importance of $\mathrm{OCB}$, and it affects their performance. OCB is one of the working attitudes commonly considered by an organization, and it becomes one of the criteria to determine if an employee makes an excellent performance. Luthans (2011) suggests that OCB has a necessary implication on the organization. The outcomes manifested into working quantity and quality and Timeliness.

Figure 2. Hypothesis Testing Results

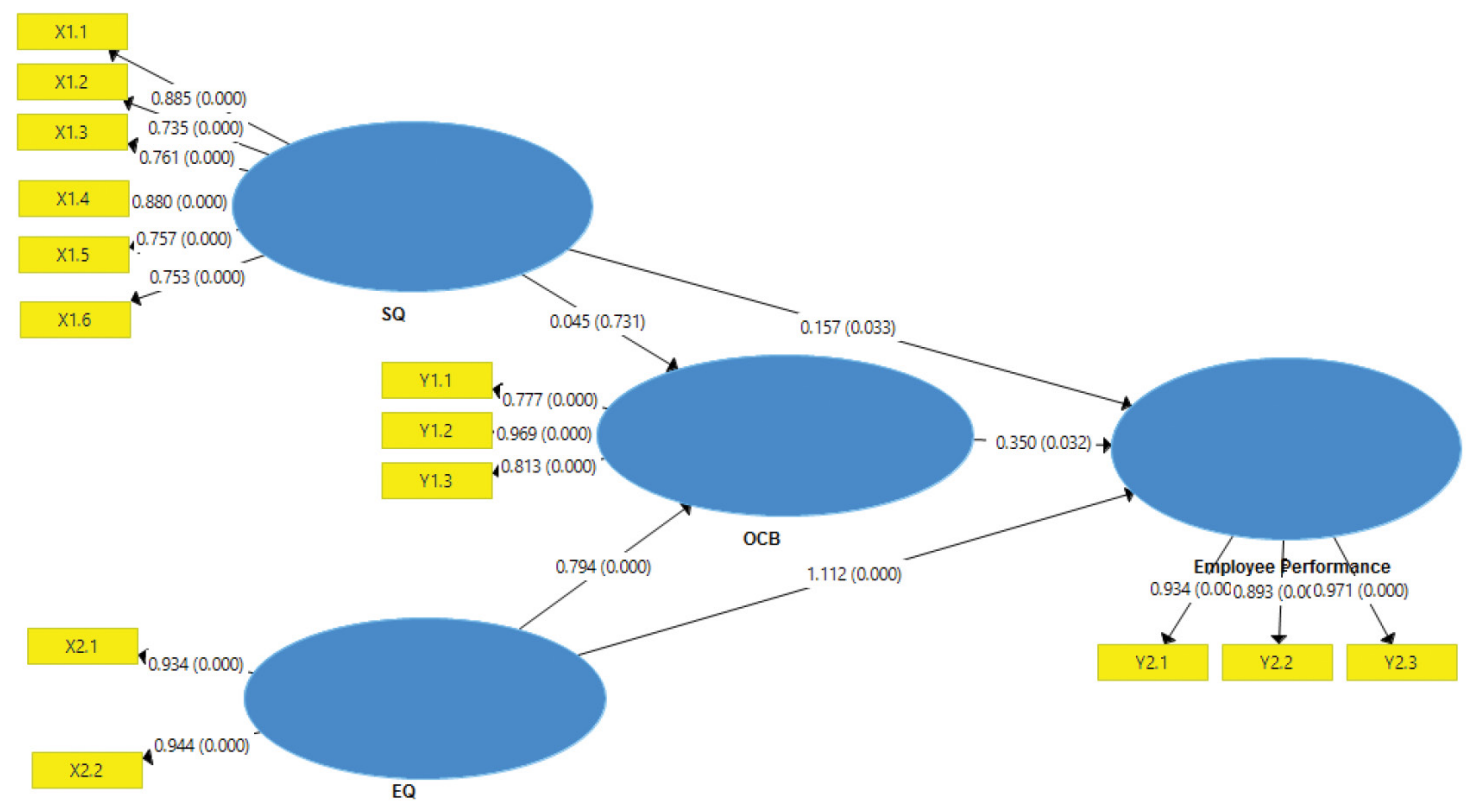

\section{Conclusion}

Spiritual intelligence has a significant effect on employee performance. It increases employee performance directly, which covers working quantity and quality and Timeliness. Spiritual intelligence does not have a significant effect on OCB. OCB affects employee performance. Spiritual intelligence cannot increase employee performance through OCB. Emotional intelligence has a significant effect on OCB, and OCB can raise employee performance directly and indirectly. Employees who can manage emotions can control their behavior during work to streamline the work processes. Thus, they give maximum results.

The researcher states that the limitation of the current study is the small number of the sample. The fact, the respondents from a single organization had made this research rigid to generalize. Further research should include more data from various organizations.

\section{References}

Agustian, G. A. (2007). Rahasia Sukses Membangun Kecerdasan Emosi dan Spiritual ESQ: Emotional, Spiritual Quotients (The Secret to Success in Building ESQ Emotional and Spiritual Intelligence: Emotional, Spiritual Quotients). Jakarta: ARGA Publishing. 
Anwar, M., A., \& Osman-Gani, A. M. (2015). The Effect of Spiritual Intelligence and Its Dimensions on Organizational Citizenship Behavior. Journal of Industrial Engineering and Management, 8(4), 1162-1178.

Arvind, H., Asra, M. S., \& Humain, A. A. H. (2015). Antecedents of Organizational Citizenship Behavior (OCB) in Banking Sector of Sultanate of Oman. International Journal in Management and Social Science, 3(1), 152-164.

Basu, E., Pradhan, R. K., \&Tewari, H. R. (2017). Impact of Organizational Citizenship Behavior on Job Performance in Indian Healthcare Industries. International Journal of Productivity and Performance Management, 66(6), 780-796. https://doi.org/10.1108/ IJPPM-02-2016-0048

Bighami, M. K., Farshid, A., \& Aliakbar, M. S. (2013). The Effect of Emotional Intelligence on Work-Family Conflict among Employees in Manufacturing Environment Using Structural Equation Modelling. Shiraz Journal of System Management, 1(2), 67-79.

Chelagat, L. J., Kiprop, C. P., \& Kembai, A. (2015). Effect of Organizational Citizenship Behavior on Employee Performance in Banking Sector Nairobi County, Kenya. International Journal of Business, Humaniora and Technology, 5(4), 55-61.

Chin, S. T. S., Anantharaman, R. N., \& Tong, D. Y. K. (2011). Emotional Intelligence and Organisational Citizenship Behaviour of Manufacturing Sector Employees: An Analysis. Management, 6(2), 107-125.

Gan, J. L., \& Yusof, H. M. (2018). Does Emotional Intelligence Influence Organizational Citizenship Behavior among Engineers? A Conceptual Paper. in Proceedings of the International Conference on Industrial Engineering and Operations Management, Bandung, Indonesia, March 6-8, 2018.

Harwiki, W. (2016). Impact of Servant Leadership on Organization Culture, Organizational Commitment, Organizational Citizenship Behaviour and Employee Performance in Women Cooperatives. Procedia-Social and Behavioral Sciences, 219, 283-290. https:// doi.org/10.1016/j.sbspro.2016.04.032.

Indarti, S., Solimun., Fernandez. R., A., \& Hakim, W. (2017). The Effect of OCB in Relationship between Personality, Organizational Commitment and Job Satisfaction on Performance. Journal of Management Development, 36(10), 1283-1293. https://doi. org /10.1108/JMD-11-2016-0250.

Khawaja, S. F. (2017). Impact of Spiritual Intelligence on Employee Task Performance and OCB. Mediating Role of Self Efficacy, Moderating Role of Collectivist Culture of Pakistan. Jinnah Business Review, 5(1), 34-45.

Luthans, F. (2011). Organizational Behavior. An Evidence - Based Approach. $12^{\text {th }}$ Edition. New York: McGraw - Hill.

Maharani, V. E., Troena, E. A., \& Noermijati, N. (2013). Organizational Citizenship Behavior Role in Mediating the Effect of Transformational Leadership, Job Satisfaction on Employee Performance: Studies in PT Bank Syariah Mandiri. Malang East Java. International Journal of Business and Management, 8(17), 1-12. 
Mangkunegara, A. P. (2001). Manajemen Sumber Daya Manusia Perusahaan (Corporate Human Resource Management). Bandung: Remaja Rosdakarya.

Mayer, J. D., Mayer, J. D., \& Caruso, D. R. (2004). Emotional Intelligence: Theory, Finding, and Implication. Psychology Inquiry, 15(3), 197-215.

Meisler, G. (2013). Empirical Exploration of the Relationship between Emotional Intelligence, Perceived Organizational Justice and Turnover Intentions. Employee Relations, 35(4), 441-455. https://doi.org/10.1108/ER-05-2012-0041.

Muhdar, H. M., \& Rahma, S. (2015). The Influence of Spiritual Intelligence, Leadership, and Organizational Culture on Organizational Citizenship Behavior: A Study to Islamic Bank in Makassar City. Al-Ulum, 15(1), 135-156. https://doi.org/10.30603/ au.v15i1.219

Organ, D. W. (2006). Treating Employees Fairly and OCB: Sorting the Effect of Job Satisfaction, Organizational Commitment and Procedural Justice. USA: Plenum Publishing Corporation.

Overstreet, R. L. (2016). The Relationship between Leaders Emotional Intelligence and Employee Organizational Citizenship Behavior and Job Related Affective Well-Being. Unpublished Dissertation. Michigan: Andrews University

Podsakoff, P. M., MacKenzie, S. B., Paine, J. B., \& Backrach, D. G. (2000). Organizational Citizenship Behaviours: a Critical Review of the Theoretical and Empirical Literature and Suggestions for Future Research. Journal of Management, 26(3), 513-63.

Rahgozar, H., Keshavarzi, M., \& Mahdavi, M. (2014). Relationship between Spiritual Intelligence and Organizational Citizenship Behavior of Shiraz Azad University Staff. Applied Mathematics in Engineering, Management, and Technology, The Special Issue in Management and Technology. 1347-1353.

Rezvani, A., Rowena, B., \& Pouria, K. (2018). Investigating the Relationships among Team Emotional Intelligence, Trust, Conflict and Team Performance. Team Performance Management, 25(1/2), 120-137. https://doi.org/10.1108/TPM-03-2018-0019.

Robbins, S. P. (2006). Perilaku Organisasi: Konsep, Kontroversi dan Aplikasi (Organizational Behavior: Concepts, Controversies and Applications). $2^{\text {nd }}$ Ed. Jakarta: Prenhallindo.

Sani, A. S., \& Troena, E. A. (2012). Pengaruh Kecerdasan Emosional dan Kecerdasan Spiritual terhadap Kepemimpinan Transformasional, Kepuasan Kerja dan Kinerja Manajer: Studi di Bank Syari'ah Kota Malang (The Influence of Emotional Intelligence and Spiritual Intelligence on Transformational Leadership, Job Satisfaction and Manager Performance: Study at the Syari'ah Bank of Malang). Jurnal Aplikasi Manajemen, 10(4), 693-709.

Saphiro, L. E. (2003). Mengajarkan Emotional Intelligence pada Anak (Teaches Emotional Intelligence in Children). Jakarta: Gramedia.

Siddiqui, R. S., \& Hassan, A. (2013). Impact of Emotional Intelligence on Employees' Turnover Rate in FMCG Organizations. Pakistan Journal of Commerce and Social Sciences, 7(2), 394-404. 
Stephens, J. P., \& Carmeli, A. (2016). The Positive Effect of Expressing Negative Emotions on Knowledge Creation Capability and Performance of Project Teams. International Journal of Project Management, 34(5), 862-873. https://doi.org/ 10.1016/j. ijproman.2016.03.003 